\title{
Social capital factors in disaster risk reduction on West Sumatera non-engineered house
}

\author{
Yervi Hesna ${ }^{1, *}$, Benny Hidayat ${ }^{1}$ \\ ${ }^{1}$ Department of Civil Engineering, Universitas Andalas, Padang, Indonesia
}

\begin{abstract}
The increasing of earthquake vulnerability in Padang City based on earthquake zoning map demanded preparedness from the community. To ensure that the house is built in accordance with the concept of the non-engineered house, so it is more secure and minimizes the risk of casualties and losses caused by the earthquake. For the people who live in disaster-prone regions, it is important to build social capital in disaster preparedness, not just on technical issues. Technical factors are not enough to educate the community, besides it requires non-technical factors that may play a significant role in disaster reduction in the community. This study intends to identify the social capital factor that is needed in the application of earthquake-resistant housing concept in the implementation of non-engineered house construction as an effort to reduce disaster risks by the community. Social capital is identified from the relationship of homeowners with builders implementing the construction of the non-engineered house. The research location was conducted in Padang city of West Sumatera Province. Through this research, it is hoped that in the future, it will produce social-related policies that help local governments to encourage the increase of public awareness in realizing the construction of non-engineered houses.
\end{abstract}

\section{Introduction}

National Geographic Magazine in March 2005 declares that Padang City is one of the cities with high levels of vulnerability to earthquakes and tsunami in the world. On September $30^{\text {th }}, 2009$ earthquake, according to data from the Regional Disaster Management Agency (BPBD), there were 1,117 people dead, two missing, 2,902 injured, and 249,833 houses damaged. From several types of buildings and infrastructure, the damage to the nonengineered house is of particular concern as it functions as a residence of the community. The results of research and observations in the field on the damage caused by the earthquakes that the largest number of damaged buildings are buildings built by the community traditionally, with a simple construction method, without a proper construction technology, and structure analysis that can produce resistant buildings earthquake [1].

With the increasing of earthquake vulnerability in West Sumatera based on earthquake zonation map published by PUPR Ministry, demands preparedness from the community in ensuring that the houses are built following the concept of earthquake resistant housing to

${ }^{*}$ Corresponding author: yervi@eng.unand.ac.id 
be more secure and minimize the risk of casualties, and losses caused by the earthquake. In the implementation of earthquake resistant house construction depends on the parties involved in the construction, one of which is the community itself as the owner of the house.

There have been many guidelines and practical guidance that has been issued by the government as an effort to assist the community in the implementation of the earthquakeresistant house. However, it is believed that until now it has not played many roles in mobilizing the community to be active in disaster risk reduction [2]. For the communities living in hazardous areas other than structural risk reduction measures, it is important to develop non-structural measures too. Social aspect consideration in managing disaster risk reduction at the community is important at present [3].

Based on this it can be concluded that the technical factor alone is not enough to educate the community, besides it requires non-technical factors that may act a very significant role in terms of disaster risk reduction in the community. This non-technical factor is called social capital. Scientific research on the function of social capital in disaster risk reduction in communities is still limited whereas social capital can serve as 'tools' in disaster risk reduction [3]. Thus through this research is expected to get answers what social capital factors determine in the successful implementation of the earthquake-resistant housing concept are.

\section{Literature review}

\subsection{Some research about non-engineered house in Indonesia}

The awareness of the need to build non-engineered house has not been understood by all levels of society even though the incidence of earthquakes continues to recur. According to Morib [2], after the earthquake in Yogyakarta in 2006 showed that people still maintain old buildings that are built without using reinforcement and concrete, with walls of lime and mashed red brick.

Similarly, research conducted by Hesna [4] to five developers in Padang City. After the earthquake of Padang in 2009, seen still lack of attention in realizing their products that meet the criteria of the non-engineered house. Lack of attention from developer company management with insufficient efforts in increasing the capacity and competence of its employees towards the control of earthquake-resistant housing materials. This research shows that only $20 \%$ of the respondents at the company level have participated in the earthquake-resistant house training. The quality of products produced by Developer is still relatively far from non-engineered house standards. Low quality of the material, unavailable of earthquake-resistant structural elements, less reinforcement detail, built on unstable soils are the most prominent concerns in building houses in Yogya and Padang [2, 4].

Prihatmaji [5] and Poerwodihardjo [6] emphasized the importance of earthquake resistant counseling given to the community. With this earthquake-resistant house extension program, it is hoped that it can add insight and prepare the community to face earthquakes and reduce the impact of the earthquake. Research by Hidayat and Egbu [14] echo similar situation, stated that human resources factor is one of the critical success factors (CSF) in post-disaster reconstruction. The availability of knowledgeable on the earthquake-resistant house may lead to better quality of reconstructed houses. Homeowners also play an important role to have the earthquake-resistant house, as a decision to adopt it is on them. Therefore knowledge transfer about non-engineered house should be conducted to both of them and house owners. 


\subsection{The role of social capital in disaster risk reduction}

It is argued that the disaster is related to the social structure of the society. When the disaster happens, it does not affect natural and/ or technical but also has social and economic impacts. People are more focused on technical problems when talking about disasters, but that is not enough. A social approach is needed in the community to overcome disasters, that is why disaster researchers had already regarded the role of social capital in disaster management.

How can social capital emerge? Social capital is potential resource that encourages multiple functions to form mutual benefits among civil society. The members of the society bonded by a formal or informal [3] both internal and external to a community [7] to form social capital. People use their social networks and connections both within and outside their communities, to get resources and opportunities [8].

The effective utilization of social capital is crucial in the building of community and institutional capacities in disaster management projects [9]. Several disasters in 10 different countries have been shown that social capital played an important role in disaster management, but very few studies overview on how social capital helps in improving risk reduction [3].

The three-step involved in cultivating social capital as seen in Fig. $1[3,7,9,10]$ :

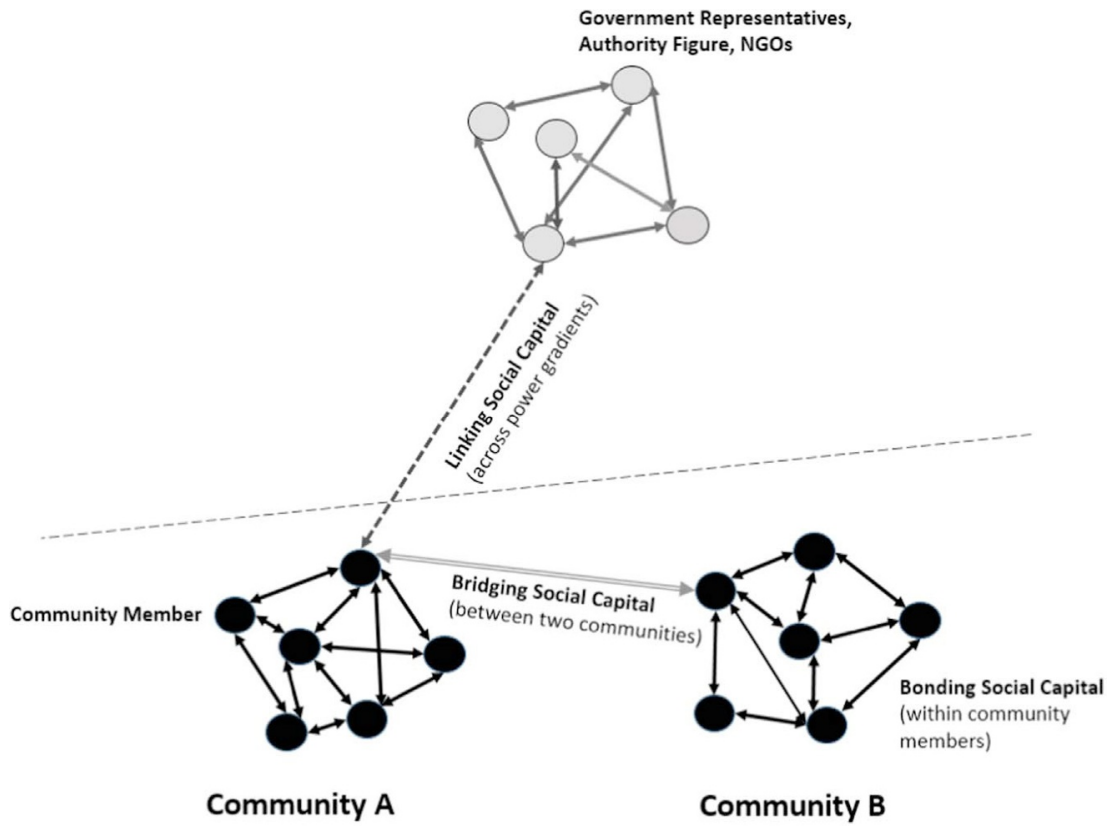

Fig. 1. The three-step involved in cultivating social capital [3].

1) Communities bonding. The utilization of social capital begins with community bonding. Bonding social capital is a form of networking between people, which denotes ties in similar situations. Some attributes used to describe bonding social capital, which are social integration, social cohesion, solidarity, networking, two-way communication, a sustained interaction between and among the members, effective coordination of community activities, collaboration on and support of members' activities, the fostering of leadership qualities, and giving a hand to other community members. 
2) Communities bridging. The next step in social capital formation is extended relation to other communities in the society. At this point, groups and interested community members can form an alliance, and a coalition to identify the needs of collaboration between them.

3) Communities Linking with some institutions. A network which reaches out to people in different situations can form linking social capital. This social capital is developed among various elements of communities, the government, and other organizations that have generally supported in mitigating the impact of natural disasters. Vertical links between a community and individuals, between groups or networks outside a community, are also a great significance for a strong civil society. Linking social capital enables community members to drag a wider range of resources than what is attainable in the community.

\section{Data and methods}

This field survey is qualitative research based on data from the primary sources. This survey was conducted in July 2018, almost nine years after the earthquake hit Padang City in 2009. Study areas reach three districts that are Pauh District, Teluk Bayur District, and Nanggalo District, can be shown in the following figure:

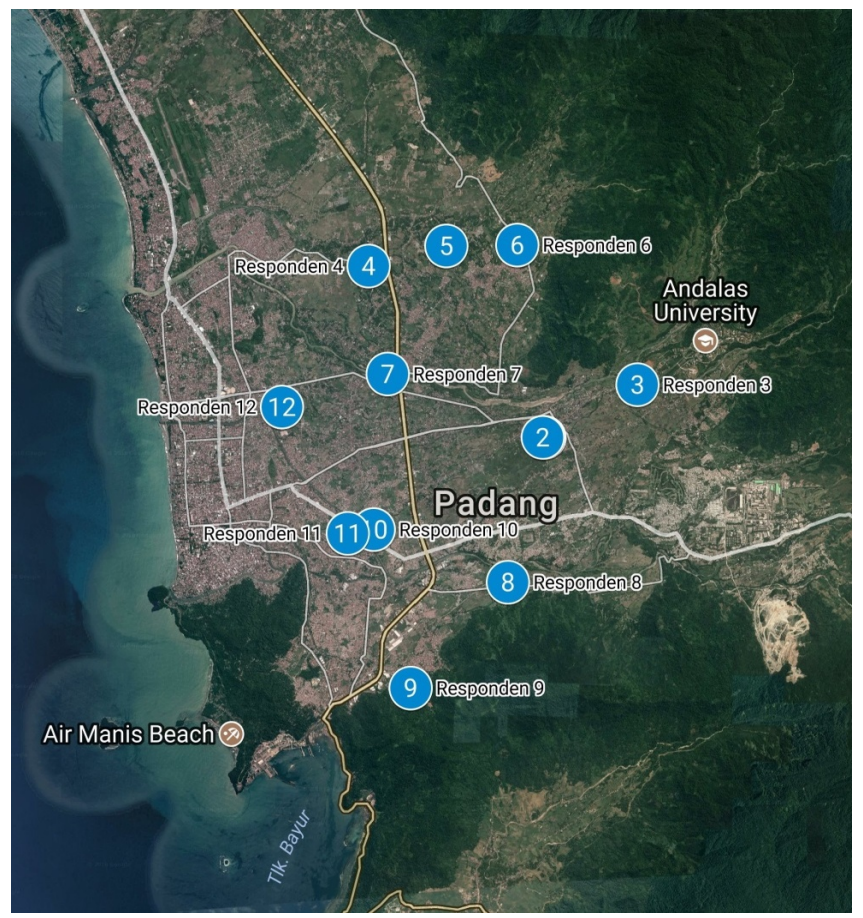

Fig. 2. Survey location in Padang city.

The detailed qualitative data sources, respondents, selection procedures, and data collection tools are presented in Table 1.

Interviews were conducted with homeowners and at each project site. Each interview serves to see how the existing social capital homeowners and in realizing the earthquakeresistant house.

Six out of the twelve homeowners are female and the majority work as self-employed. Seven of the twelve only finished junior high school while the rest were high school 
graduates. All of them have no engineering educational background. The majority of already have work experience of more than 15 years, and only two builder has less than ten years of experience.

Table 1. The data of field survey.

\begin{tabular}{|c|c|c|c|}
\hline $\begin{array}{c}\text { No. of } \\
\text { Project }\end{array}$ & Location & Selection procedure & $\begin{array}{c}\text { Method of data } \\
\text { collection }\end{array}$ \\
\hline 1. & Binuang Kampung Dalam & Purposively & Interview \\
\hline 2. & Binuang Kampung Dalam & Purposively & Interview \\
\hline 3. & Limau Manis & Purposively & Interview \\
\hline 4. & Gunung Sarik & Purposively & Interview \\
\hline 5. & Gunung Sarik & Purposively & Interview \\
\hline 6. & Gunung Sarik & Purposively & Interview \\
\hline 7. & Korong Kadang & Purposively & Interview \\
\hline 8. & Kampung Jua & Purposively & Interview \\
\hline 9. & Pengambiran & Purposively & Interview \\
\hline 10. & Parak Karakah & Purposively & Interview \\
\hline 11. & Kubu Marapalam & Purposively & Interview \\
\hline 12. & Alai Parak Kopi & Purposively & Interview \\
\hline
\end{tabular}

Table 2. Measurement indicator of social capital.

\begin{tabular}{|c|c|}
\hline Source & Indicator of measurement \\
\hline $\begin{array}{l}\text { Social participation and } \\
\text { support }\end{array}$ & $\begin{array}{l}\text { 1. Participation of neighbors/relatives in the selection } \\
\text { the builder. } \\
\text { 2. Participation of other builder community member. }\end{array}$ \\
\hline $\begin{array}{l}\text { Reciprocity, shared } \\
\text { values, and Trust }\end{array}$ & $\begin{array}{l}\text { 1. } \text { Trust in work results. } \\
\text { 2. Supervising in the construction process. } \\
\text { 3. Participation in material selection, material purchase, } \\
\text { job specification, and house design }\end{array}$ \\
\hline $\begin{array}{l}\text { Regulation and formal } \\
\text { institution }\end{array}$ & $\begin{array}{l}\text { 1. Rules and guidelines. } \\
\text { 2. Institution, associations, and network involvement. }\end{array}$ \\
\hline
\end{tabular}

\section{Results and discussion}

\subsection{Bonding social capital}

From field survey in the study area, the majority of homeowners get consideration from other community members in the selection of who will work on their house. Immediate family members and relatives and/ or nearest neighbors generally give considerations. Similarly, the implementation of house building activities, sometimes homeowners also get 
input or consideration related to the requirements of the earthquake-resistant house from nearby neighbors who witnessed the construction of homes.

Meanwhile, seldom make requests for suggestions and considerations from another fellow who have done similar work related to the construction of simple earthquakeresistant homes.

According to Kerr [8], bonding social capital is earned from relations between people in more similar settings, typically among reasonably homogeneous groups of people. However, the relationship of the owner of the house with other members of the community and the relationship of the builder with the other looks different. There is no strong group loyalty between builder group members.

\subsection{Bridging social capital}

To ensure the implementation of their house construction adopted the principle of earthquake resistant house, all homeowners indicated that they were jointly involved in supervising the construction of his house. Ten out of the twelve respondents stated that they had an understanding of earthquake-resistant house principle obtained from socialization, brochures, pamphlets, and information from them.

Concerning building materials, only three homeowners claim to cooperate with regarding determining the specifications, and brands and purchasing materials. Nine other respondents stated that matters relating to building materials were left entirely to them. Nevertheless, all the respondents still said that they fully trust the related to the quality and the results of building the house is done.

Shared value, trust, and reciprocity are the factor that used in determining bridging capital. These criteria are used as an indication that the bridging capital between homeowners and here is likely to be reasonably strong.

\subsection{Linking social capital}

The construction practice of the has been based on personal work experience and discussions with the fellow. There are no official organizations or institutions that accommodate. Even though the majority of the said they were checking in the execution of house construction, but the accuracy could not be trusted. Because the worker does not have a guideline in working, everything is done based on previous experience

Even though all the said, they understood the requirements of earthquake resistant for non-engineered houses there was no mechanism/regulation from institutions or associations that supervise of the work of the builder.

So in the construction of the house, the only guided by books, brochures or pamphlets obtained from the socialization of non-engineered earthquake-resistant house.

Linking social capital between homeowners and with government institution might have been limited. These findings recommend that the linking capital in term of construction of non-engineered house must be improved. There was the potential for building linking the social capital with the willingness and activity of both parties. Active participation from local/ district government is the need in supervising the construction of the non-engineered house to ensure meet earthquake-resistant house.

\section{Conclusions}

Social capital has a high potential useful for disaster risk reduction and preparedness in the substance of non-engineered house construction. Social capital plays an active role in 
strengthening capacities at the community level so that better risk reduction can be achieved [3]. Bonding and bridging social capital allow community members to undertake risk reduction if the earthquake happened. Strengthening social networks are essential tools for transferring knowledge and warning message before the disaster [11]. It also provides an opportunity to work together between homeowners and gains some additional social capital through mutual help and strengthening network ties and so on. Social capital can be a modal at community member in case of the lack of governmental contribution in disaster planning, and recovery [7]. There is a better sharing of knowledge, between homeowners, and neighbors if they have social capital. This makes them more knowledgeable in the construction of the non-engineered house. So that the quality of the implementation of earthquake resistant for West Sumatera non-engineered house is better.

This research confirms that there is missing the social capital issue in policy documents. Thus it is crucial for government agencies to adopt many policies and programs which would increase the bonding social capital among community members and strengthen social networks in disaster risk reduction.

This research publication was supported by Community Service and Research Institution of Andalas University (LPPM) under the Grant contract no. 19/UN.16.17/PP.RD/LPPM/2018

\section{References}

1. T. Boen, EQTAP Workshop IV Kamakura (2001)

2. M.A. Morib, Majalah Ilmiah UKRIM 1 (2012)

3. S. Sanyal, J.K. Routray, Int. J. of Disaster Risk Reduction 19 (2016)

4. Y. Hesna, Proc. of the 1st Andalas Conference of Engineering (2015)

5. Y.P. Prihatmaji, W.B. Pramono, C.A. Nugroho, Jurnal Inovasi dan Kewirausahaan 3 (2013)

6. F.E. Poerwodihardjo, Bahan dan konstruksi rumah tinggal tahan gempa (2018)

7. L. Harrison, The role of social capital in disaster recilience, (Y Care International, 2014)

8. S.E. Kerr, Social capital as determinant of recilience: implication of adaptation policy (2018)

9. G.M. Mathbor, Int. Social Work 3 (2015)

10. S. Sadeka, M.S. Mohamad, M.I.H Reza, J. Manap, M.S.K. Sarkar, J. of the Social Science Res. 3 (2015)

11. Z. Yandong, Economic Stress Human Capital and Families in Asia 4 (2013)

12. R. Islam, G. Walkerden, Int. J. of Disaster Risk Reduction 17 (2017)

13. B. Hidayat, Z. Afif, AIP Conference Proc. 1903, 1 (2017)

14. B. Hidayat, C. Egbu, Proc. of the 27th Annual ARCOM Conference (2011) 